Portland State University

PDXScholar

$7-1-2018$

\title{
Reorganizing School Lunch for a More Just and Sustainable Food System In the US
}

Jennifer Gaddis

University of Wisconsin-Madison

Amy K. Coplen

Portland State University, acoplen@pdx.edu

Follow this and additional works at: https://pdxscholar.library.pdx.edu/usp_fac

Part of the Sustainability Commons, and the Urban Studies and Planning Commons

Let us know how access to this document benefits you.

Citation Details

Gaddis, J., \& Coplen, A. K. (2018). Reorganizing School Lunch for a More Just and Sustainable Food System in the US. Feminist Economics, 24(3), 89-112.

This Post-Print is brought to you for free and open access. It has been accepted for inclusion in Urban Studies and Planning Faculty Publications and Presentations by an authorized administrator of PDXScholar. Please contact us if we can make this document more accessible: pdxscholar@pdx.edu. 


\title{
REORGANIZING SCHOOL LUNCH FOR A MORE JUST AND SUSTAINABLE FOOD SYSTEM IN THE US
}

\begin{abstract}
Public school lunch programs in the United States are contested political terrains shaped by government agencies, civil society activists, and agri-food companies. The particular organization of these programs has consequences for public health, social justice, and ecological sustainability. This contribution draws on political economy, critical food studies, and feminist economics to analyze the US National School Lunch Program, one of the world's oldest and largest government-sponsored school lunch programs. It makes visible the social and environmental costs of the "heat-and-serve" economy, where widely used metrics consider only the speed and volume of service as productive work. This study demonstrates that such a narrow understanding of the labor of lunch devalues care and undercuts the potential for school food provisioning to promote ecological and feminist goals. Further, it proposes a "high road" alternative and outlines an agenda for reorganizing school food provisioning to maximize care in all its dimensions.
\end{abstract}

\section{KEYWORDS}

Social reproduction, care labor, foodservice, school food, sustainable food systems, social provisioning

JEL Codes: B54, H4, I3

\section{INTRODUCTION}

School lunch is a contested political arena shaped by government agencies, civil society activists, and powerful agri-food companies concerned with what and how children are fed. At its most fundamental level, school lunch is also about care - a "species activity that includes everything we do to maintain, continue, and repair our world so that we may live in it as well as possible" (Fischer and Tronto 1990: 40). The social organization of school lunch impacts ecological sustainability, economic development, and social justice (Robert and Weaver-Hightower 2011; Morgan and Sonnino 2013). It is not just what children are fed at school that matters, but also who is being fed, who performs the work of feeding, how, and for what

\section{(c) 2017 IAFFE}


purpose (Sandler 2011). In this contribution, we examine the intersection of sustainability, ecology, and care at the site of government-sponsored school lunch programs, responding to Julie Nelson's call for economics to concern itself "more with concrete issues of provisioning related to the actual social and natural environment" (1996: 131).

The act of feeding children is vital to social reproduction, which Giovanna Di Chiro defines as "the intersecting complex of politicaleconomic, socio-cultural, and material-environmental processes required to maintain everyday life and to sustain human cultures and communities on a daily basis and intergenerationally" (2008: 281). In many countries, including the United States, social reproduction has been largely decollectivized, becoming the responsibility of the family to be secured in the home or private sphere (Federici 2004; Bakker 2007; Nakano Glenn 2012). Food insecurity - or lack of physical, social, and economic access to sufficient, safe, and nutritious food that meets people's dietary needs and food preferences for active and healthy lives (Food and Agriculture Organization 2015) - is a symptom of a broader crisis of social reproduction. At specific moments in global, national, and local histories, government and civil society organizations have stepped in to mediate this crisis by offering free or heavily subsidized school lunches.

The social organization of school lunch programs is an evolving process that varies both within and across country contexts (Robert and Weaver-Hightower 2011; Morgan and Sonnino 2013; Oostindjer et al. 2016). Program development in industrialized countries follows three distinct phases (Oostindjer et al. 2016). Between 1850 and 1950, programs were established to address hunger and malnutrition among lower socioeconomic groups and, in cases like the US, to redistribute surplus agricultural commodities. In the 1970s, some countries improved the quality and nutritional profile of school lunches to address growing concerns about the health impacts of feeding children highly processed foods. The third and contemporary phase encompasses a wider range of health and sustainability concerns (Morgan and Sonnino 2013). In less industrialized countries, the United Nations (UN) has supported school lunch programs as a means for advancing sustainable and equitable development (World Food Programme 2011). Currently operating in thirty-seven countries, the UN Home Grown School Meals initiative promotes local food and seeks to empower producers and consumers to participate in shaping their own programs (World Food Programme 2016). There is tremendous potential, across country contexts, for both long-established and newly developing school lunch programs to promote sustainable diets, which the UN Food and Agriculture Organization (FAO) defines as "diets with low environmental impacts which contribute to food and nutrition security and to healthy life for present and future generations" (2010). Such diets are "protective and respectful of 
biodiversity and ecosystems, culturally acceptable, accessible, economically fair and affordable; nutritionally adequate, safe and healthy; while optimizing natural and human resources" (FAO 2010). However, as our analysis underscores, school lunch programs can become co-opted in ways that undermine their public value.

Our primary case is the US National School Lunch Program (NSLP), one of the oldest and largest school lunch programs. We bring together literature from political economy, critical food studies, and feminist economics to highlight how the "heat-and-serve" economy erodes the public value of the NSLP and increases its resource intensity. Using Marilyn Power's (2004) social provisioning methodology, we uncover how the distribution of power and the organization of labor within the NSLP shape the economic, public health, and ecological impacts of school lunch. This methodology highlights the importance of social norms in shaping economic systems (Himmelweit 2002) and provides a platform for feminists to critically investigate relationships between humans and nature as mutually constitutive. Power (2004: 5) defines social provisioning "not as a rigid template or delineation of boundaries, but as a set of guideposts in a rapidly developing field of knowledge," including five intimately interconnected components: (1) the incorporation of caring and unpaid labor as fundamental economic activities, (2) the application of well-being as a measure of economic success, (3) the analysis of economic, political and social processes and power relations, (4) the inclusion of ethical values and goals as an intrinsic part of the analysis, and (5) the interrogation of differences by class, race-ethnicity, and other factors (Power 2004: 3). Following an integrated analysis of social provisioning within the contemporary NSLP, we put forward an agenda for reorganizing school lunch to serve both feminist and ecological ends.

\section{THE POLITICAL ECONOMY OF THE NSLP}

The US Congress established the not-for-profit NSLP in 1946 as a measure of national security to "safeguard the health and well-being of the Nation's children and to encourage the domestic consumption of nutritious agricultural commodities and other foods" (US Department of Agriculture [USDA] 2014). ${ }^{1}$ The NSLP is a microcosm of the US food system, operating within what agrarian studies scholars refer to as the "corporate food regime" (1980s-present), characterized by international trade liberalization, post-Fordist flexible accumulation strategies, and a shift from public to private regulation (Busch and Bain 2004; Pechlaner and Otero 2010). The public sector's inability to regulate transnational trade has allowed the private sector to wield considerable power in reconfiguring the social relations of the global food system (Busch and Bain 2004). Despite concerns about the healthfulness and ecological impacts of 
133 heavily consolidated and industrialized food systems, large multinational 134 companies continue to gain power through public-private partnerships and regulations that favor their own business practices (Busch and Bain 2004). A parallel process occurred within the NSLP, with policy shifting in favor of processed food companies as school lunch became increasingly commercialized.

The reduction of food's nutritional value to individual components like fat, calories, salt, sugar, and vitamins - sometimes referred to as "nutritionism" - allows food processors to reformulate and fortify products in order to make health claims about products of minimal nutritional value (Clapp and Scrinis 2017). In the late 1960s and early 1970s, the USDA promoted scientifically nutritious "efficiency foods," like frozen and pre-plated meals, for use in the many thousands of schools that lacked kitchens and cafeterias (Levine 2008; Poppendieck 2010). Schools were allowed to outsource their lunch programs to for-profit companies. At the same time, schools were beginning to face perverse financial incentives to make money selling snack items in vending machines and à la carte lines in order to balance their budgets. The trend toward "heat-and-serve" foods accelerated throughout the 1970s, with an inflationary crisis and concerns about food waste establishing the groundwork for new legislation (Poppendieck 2010). The USDA “modernized" its commodities program by making highly processed finished products like chicken nuggets far more available to schools. Cost-cutting attempts in the 1980s and 1990s further eroded nutrition standards and brought fast food giants like Domino's and Taco Bell into school lunchrooms, where children were increasingly being treated as "customers" whose taste for salt, fat, and sugar were a source of both current and future profits for fast food franchises and powerful packaged food companies (Poppendieck 2010).

The most recent legislative reform to the NSLP, the Healthy Hunger Free Kids Act of 2010 (HHFKA), ushered in updated nutrition standards, which were quickly followed by intense rounds of lobbying by powerful agribusiness companies and trade associations that wanted to "relax" or revoke regulations that reduce their profitability. This included mandates to include more healthful foods like unprocessed fruits, vegetables, and whole grains, and fewer salty and starchy foods like potatoes and pizza (Confessore 2014). ${ }^{2}$ By 2011, the challenge of meeting tight financial constraints and complex regulatory requirements had pushed roughly one-quarter of US schools to outsource their lunch programs (Komisar 2011). ${ }^{3}$ This practice evoked criticism from labor unions and media outlets in the late 1990 s and early 2000s after evidence pointed to declining nutritional quality, conflicts of interest, and multiple cases of foodborne illness and fraud (Service Employees International Union 2005; Bogardus 2010; Komisar 2011). For-profit management companies, especially those with multi-state and multi-sector contracts, are notorious for controlling 
177 their costs by cutting food quality and reducing workers' wages and benefits (Jacobs and Graham-Squire 2010). Most school districts continue to run Q4 self-operated lunch programs, but they too face pressures to keep food and labor costs low, which further reinforces the logic of the "heat-and-serve" economy.

182

183

\section{THE LABOR OF SCHOOL LUNCH}

186

Women perform most of the food provisioning practices in schools and at home, yet they control few resources and hold little decision-making power over agri-food policy or industry practices (Allen and Sachs 2007). As a commodified form of reproductive labor, the wages and value assigned to school foodservice work is tethered to a legacy of feminization, racialization, and devaluation (England, Budig, and Folbre 2002). Over 90 percent of the estimated 420,000 foodservice workers in US K-12 schools are women (Jacobs and Graham-Squire 2010). They worked a median twenty-five hours per week and in 2008 earned a median annual income of US $\$ 9,300$, compared with forty hours per week and US\$30,000 for the workforce as a whole. Due to chronically low wages, they are about twice as likely to participate in one or more public assistance programs compared with the US workforce as a whole (36.3 percent versus 19.7 percent, respectively; Jacobs and Graham-Squire 2010).

There are some "good" jobs in school foodservice. The minority of workers covered by strong union contracts, and those with decades of seniority or highly specialized skills, earn upwards of US $\$ 15$ per hour and may qualify for employer-provided healthcare and retirement benefits. However, the vast majority of jobs in the "heat-and-serve" economy are short-hour low-wage positions without benefits. New employees are hired as temporary or substitute workers who fill shifts as needed. After gaining a permanent position it can take a decade or more to be promoted into a full-time position with benefits. This precarious employment structure disproportionately affects single mothers and primary providers who make up a substantial portion of the K-12 cafeteria labor force (UNITE HERE! 2013). The degraded nature of their jobs harms not only the economic security and well-being of their families, but also the millions of children and families who depend on the NSLP as a care service.

Managers typically assess their operations using a metric of staffing efficiency and productivity called "meals-per-labor-hour" (MPLH; Rushing, Anderson, and Boettger 2016), which pushes schools to rely more heavily on pre-packaged food and disposable trays that have negative consequences for the health of children's bodies and the environment. Frontline cafeteria workers are judged primarily by criteria that prioritize speed in both production and service. In some schools, the lack of culinary infrastructure makes it difficult for them to prepare healthy meals (PEW Trusts 2013), 
and the pace of service is so fast that cafeteria workers barely have time to engage children, though public health research demonstrates that verbal prompts help children make healthier choices (Schwartz 2007).

Evaluating the labor of lunch predominantly through a lens of time efficiency undermines the social interactions that are vital to providing high-quality meals to children and devalues the expansive range of paid and unpaid caring activities that a social provisioning approach makes explicit. Following Nakano Glenn's (2012) typology of care work, we outline three intertwined categories of labor that cafeteria workers perform. First is direct caring - the physical care of nourishing children's bodies; the emotional care of offering reassurance and knowing children's names, life situations, and preferences; and the services required to help children and families meet their needs, like assisting with paperwork for free lunch applications and keeping track of students with allergies and special dietary needs. Second is maintaining the physical spaces where children eat: washing lunch trays, restocking napkins and utensils, and keeping serving areas clean. Third is the work of fostering relationships and social connections, also referred to as "community mothering," which includes encouraging respectful and caring behavior toward other children and adults; and connecting students to the people who grow and produce their food. For cafeteria workers who live in the communities they serve; and those who have had a long tenure at a particular school, "community mothering" also involves making connections intra- and intergenerationally between the children they feed and their extended family and neighbors.

High-quality care depends on the cultivation of sustained personal relationships (Himmelweit 2007), but degraded job conditions disrupt relationships between cafeteria workers and the children they feed. Schools across the US are struggling to recruit and retain cafeteria workers (Jacobs and Graham-Squire 2010). In some cases, cafeterias are short-staffed for months or even years at a time, which pressures workers to skip their scheduled breaks, work overtime without pay, or take on additional tasks to ensure that students are fed on time (UNITE HERE! 2013). Such self-exploitation has parallels across caring industries, where "owners and managers often seem to depend on their workers' willingness to sacrifice for their clients" (England, Folbre, and Leana 2012: 33). ${ }^{4}$ In sum, we argue that failing to recognize, value, and support cafeteria staff's ability to care for children undermines the NSLP's stated goal of "safeguard[ing] the health and well-being of the Nation's children” (USDA 2014).

\section{REPRODUCING HEALTH AND ENVIRONMENTAL RISK}

At a cost of roughly US $\$ 12.5$ billion in 2016 , the NSLP is one of the largest and most widespread child welfare programs in the US (USDA 2017a). Approximately 95 percent of public and non-profit private schools 
265 participate, feeding roughly 30.4 million children (USDA 2017b). Children

266 qualify for free, reduced-price, or full-priced meals based on their family 267 income $_{1}$ - a policy that has reinforced class and race divides throughout 268 the NSLP's history (Levine 2008; Poppendieck 2010). Non-white families 269 participate in the NSLP at higher rates (Ralston et al. 2008), as do children 270 of women employed outside the home (Datar and Nicosia 2012). Over 271 twenty million eligible children - mostly from higher-income families - do 272 not participate in the NSLP. The poor quality of school meals, perceived or 273 actual, coupled with the potential stigma of eating school lunch are just a 274 few of the reasons why eligible children may opt out (Mirtcheva and Powell 275 2009; Poppendieck 2010).

276

All school lunches, including "full price" meals, are subsidized to some extent by the federal government through a formula that dispenses cash subsidies and an allotment of agricultural commodities per child served. The maximum 2016 federal reimbursement for a "free" school lunch in the

280

281

282

283

284

285 contiguous states was US\$3.39 and US\$0.44 for a "full price" lunch (USDA 2016). These reimbursement dollars, along with revenue from full-price lunches and à-la-carte sales, help offset the cost of free and reduced-price lunches, which make up about 73 percent of the total number of lunches served (USDA 2017b).

Schools participating in the NSLP must offer a nutritionally balanced 286 meal and cover their labor, equipment, and administrative costs. To avoid dipping into general education funds, foodservice directors strive to minimize costs and maximize average daily participation (ADP). The need

289 to operate as a "business" creates an economic incentive to attract paying "customers" by selling brand-name and other commercial foods that mirror the snacks and fast foods sold in retail settings (Poppendieck 2010).Por 292 nutrition negatively impacts children's ability to excel in the classroom 293 (Taras 2005). The composition of school lunches; is therefore; especially 294 important for low-income children who are disproportionately dependent 295 on the NSLP for their energy and nutritional intake (Briefel, Wilson, and 296 Gleason 2009).

297 Over the past decade, public health professionals and policymakers 298 have focused on reforming the NSLP as a means for reducing child 299 obesity, which has tripled since 1980 (Ogden et al. 2012). Child obesity, 300 like other diet-related health risks, is distributed unevenly across class 301 and race lines (Otero et al. 2015). Between the years 2011 and 2014, 302 only 14.7 percent of non-Hispanic white children were obese, while 21.9 303 percent of Hispanic children and 19.5 percent of non-Hispanic black 304 children were classified as obese by the Centers for Disease Control and 305 Prevention (CDC; 2017). The energy balance model largely guides efforts 306 to reverse these trends, by theorizing that people gain weight when the 307 amount of calories they consume exceeds the amount of calories they 308 expend. This overly simplistic model leads policymakers and activists to 
treat poor nutrition as an individual problem of personal choice (Gibson and Dempsey 2015). It ignores structural, genetic, and environmental factors that mediate metabolic processes (Guthman 2011). It also deflects attention away from the human and environmental impacts of the energy and chemicals used in growing, transporting, and preserving school meals.

The industrialization of the food system contributes to the hundreds of chemicals, including pesticides, bisphenol A (BPA), and phthalates that are now part of the human "body burden," or the sum of synthetic and naturally occurring chemicals present in an individual's body (CDC 2009). ${ }^{5}$ Chronic exposure to environmental toxins, particularly endocrinedisrupting chemicals, can affect fat tissue development (Newbold et al. 2008), disrupt appetite and metabolism (Tabb and Blumberg 2006), and heighten the risk of certain reproductive and behavioral disorders and cancers (Krimsky 2002). Mediating children's chemical body burdens through individual acts of "precautionary consumption" (MacKendrick 2014) requires inputs of additional time and money that many lowincome caregivers cannot afford. What's more, attempting to navigate this landscape of chemical risk creates yet another burden for women who are deciding what to feed their children or whether to let them participate in the NSLP (Cairns, Johnston, and MacKendrick 2013).

During Congressional reauthorization of the NSLP in 2010, nutrition standards were updated to more closely match the Dietary Guidelines for Americans (DGA). Every five years, beginning in 1980, the US Department of Health and Human Services and the USDA have jointly published the DGA - a document that is-meant to reflect the most current, sciencebased nutrition advice (Office of Disease Prevention and Health Promotion 2017). Recommendations from an advisory committee comprised of independent experts in the fields of nutrition, medicine, and public health inform the final DGA. Though based on scientific evidence, the DGA are far from apolitical (Nestle 2013). Large agri-food companies and trade associations shape nutrition science and policy through selective funding of scientific research, professional lobbying, and donations to lawmakers and professional organizations (Brownell and Warner 2009). Notably, the advisory committee for the 2015-20 DGA included evidencebased recommendations on environmental sustainability and its relation to the American diet (Wood-Wright 2016). However, these considerations were dropped from the final DGA, despite nearly three-quarters of adults in the US supporting the inclusion of environmental provisions and the promotion of sustainable agriculture practices in the DGA (WoodWright 2016). At present, the DGA and the social provisioning of the NSLP reinforce the agri-food industry's influence over nutrition standards, reproduce health disparities along lines of race and class, and limit federal support for sustainable diets. 
The social provisioning methodology requires that we extend our analysis of well-being beyond children's bodies to the health and sustainability of the environments they inhabit. A growing number of metrics point to the un-sustainability of the dominant global industrial food system (Heller and Keoleian 2003). From an environmental standpoint, these include: loss of genetic diversity, escalating rates of agricultural land conversion, high rates of soil loss and groundwater withdrawal, intensive reliance on fossil fuels and synthetic chemicals, and the generation of large amounts of food waste.

362

363 From a socioeconomic perspective, indicators include: the limited income and profitability of farming, the aging demographics of farm operators, the precarious legal status and labor conditions of many food chain workers, and the high degree of capital consolidation occurring in the food industry (Heller and Keoleian 2003). From a public health standpoint, pesticide exposures (via farm-based application and food intake) raise the risk for some cancers and reproductive disorders; concentrated animal feeding operations contribute to widespread outbreaks of foodborne pathogens; and excessive use of antibiotics in farm animals can lead to resistant strains of microbes in humans (Horrigan, Lawrence, and Walker 2002).

Alternative food networks and movements have grown in response to the environmental, socioeconomic, and public health concerns related to the industrial food system. In the 1960s and 1970s, "back to the land" movements sought to create alternatives through local and organic agriculture, natural food cooperatives, and vegetarian diets (Belasco 2014). At the same time, communities of color drew on the momentum of civil rights movements to organize against the exploitation of migrant farmworkers, framing labor as a critical social justice issue. Beginning in the 1980 s, new alternative food movements and initiatives emerged and shifted their focus toward environmental sustainability (Allen et al. 2003; Alkon and Agyeman 2011). The contemporary alternative food movement hinges mainly, though not exclusively, on initiatives both by and for the white middle class who decry a perceived disconnect with "where our food comes from" and champion a return to a romanticized agrarianism to combat the alienation of modern urban life (Alkon and Agyeman 2011; Minkoff-Zern 2014). The dominant discourse of alternative food politics has thus shifted from the public to the private sphere, away from collective organizing and toward "voting with one's fork" and affecting change primarily through market-based mechanisms (Brown and Getz 2008; Guthman 2008; Jaffee 2012).

Alternative food movement activism within the context of the NSLP has focused largely on support for school gardens and farm-to-school (FTS) programs. A grassroots group of farmers, parents, and nonprofit organizations launched the FTS movement in the early 1990s (National 
Farm to School Network 2016a). FTS - which includes some combination of local purchasing, school gardens, and educational initiatives - has gained significant traction among policymakers and practitioners in the past decade. The USDA established a formal FTS program in 2012, through which it administers grant funding and technical assistance.

FTS programs improve student health (Moss et al. 2013), increase participation in the NSLP, and provide a range of important community, environmental, and economic benefits that are not directly captured using the NSLP's current metrics (Kloppenburg and Hassanein 2006; National Farm to School Network 2016b). Proponents argue that FTS shifts children's relationship to food, nature, and community in ways that are healthier and more ecologically sustainable, while at the same time directing public funds to local farmers. Examining the FTS movement through the lens of social provisioning, particularly with regard to politicaleconomic processes and power relations, reveals a more complicated picture. Some critical food studies scholars argue that FTS reproduces much of the rhetoric and practices of neoliberal governance through contingent labor relations, reliance on private funding sources, and the devolution of responsibility to the local level (Allen and Guthman 2006).

While over 42 percent of US school districts participated in at least one FTS activity in 2015 (USDA 2016a), reliance on state and local governments and civil society organizations to fill the funding gap has led to highly unequal development, with poorer states participating less in FTS programming (Lyson 2016). Furthermore, cumbersome USDA procurement regulations and the ubiquity of "heat-and-serve" cookery make it difficult for schools to develop robust FTS programs. ${ }^{6}$ Connecting with local farmers, applying a "geographic preference" specification when writing bid documents, and purchasing the necessary equipment to safely store, cook, and serve fresh food all require additional staff time and financial resources that poorer school districts may not have. Despite overwhelming public support for FTS, ${ }^{7}$ less than half of 1 percent of the annual federal budget for the NSLP is allocated to support these programs. ${ }^{8}$ Instead of investing in FTS, most of the NSLP budget supports industrially produced food and reinforces the power asymmetries of the corporate food regime.

Moreerer, social provisioning methodology pushes us to explicitly consider the value of paid and unpaid care work and to incorporate ethical goals and values as part of our analysis of FTS programs. As with other alternative food initiatives, an uncritical approach could reproduce the gender, class, and racial hierarchies of the industrial food system, which are not partial to the length of supply chains and often manifest at the local scale (DuPuis and Goodman 2005; McMahon 2005; Born and Purcell 2006). For example, critical food scholars have shown that the production of local food relies on the self-exploitation of farmers (Galt 2013) and/or 
441 the cheap labor of farm workers who are vulnerable to the same types 442 of exploitation as those who toil in the global industrial food system 443 (Gray 2014). K-12 cafeteria jobs do not necessarily improve 444 local food is being prepared and served. The educational wing of FTS 445 depends heavily on unpaid volunteers and low-paid service members of 446 organizations like AmeriCorps whose work supports school gardens, field 447 trips, and local food tastings (Allen and Guthman 2006). Thus, in order 448 to avoid the "local trap," which posits that local eating as inherently more 449 ecologically sustainable and socially just (Born and Purcell 2006), FTS 450 advocates must focus on dismantling the structural inequalities embedded 451 within the NSLP and adopt what Charles Levkoe (2011) refers to as a 452 453 "transformative orientation."

\section{REORGANIZING THE PUBLIC WORK OF FEEDING}

The preceding critique of the NSLP points to numerous ways that the current social provisioning of school lunch harms children, cafeteria workers, and the environment. Reorganizing school lunch in order to maximize the public benefits of care as an interspecies and intergenerational activity is a multifaceted endeavor. Informed by critical food studies (Gottlieb and Joshi 2010; Alkon and Agyeman 2011; Levkoe 2011) and the social provisioning methodology (Power 2004), we outline five properties of such a food system:

466

(1) Food chain workers who grow, process, distribute, prepare, and serve food earn a decent living and are respected for the role they play in feeding others.

(2) The health of human and nonhuman species is actively protected and restored when necessary.

(3) Food production, transport, storage, processing, and packaging are designed to minimize the use of fossil fuels, chemicals, water, and other resources.

(4) Regional food cultures that promote vibrant communities and meaningful connections to the environment are actively supported.

(5) Producing and consuming food is safe and healthy for people of all socioeconomic class, gender, race/ethnicity, and legal statuses.

Our agenda for reorganizing school lunch in ways that better conform to these properties is informed by scholarship on "high road" labor market strategies for the care sector (Folbre 2006); and by the work of planning scholars Kevin Morgan and Roberta Sonnino (2013) who articulate a new "moral economy" of school food based on three factors: a broad conception of care, public procurement as a tool for enhancing social justice and ecological sustainability, and active citizen participation in the design and 
delivery of school food programs. In putting forward this agenda, we identify several "way stations," or intermediate institutional innovations, that may only partially embody the values of the ideal alternative, but move the system in the right direction (Wright 2007).

\section{Expanding culinary capacity}

Scratch cooking is a cost-effective way to expand the variety of healthy lunches that children are offered (Woodward-Lopez et al. 2014). Countries as diverse as Japan, Italy, and Brazil all emphasize fresh cooking in their national school lunch programs (Hager 2015; Liquori 2006; Otsuki 2011). Before the mass industrialization of the NSLP, many US schools had production kitchens that were outfitted with versatile equipment that allowed cooks to prepare recipes from scratch (Poppendieck 2010). Staff followed nutritional requirements and learned a wide range of culinary skills while on the job: baking bread, scaling recipes, substituting ingredients, and even basic butchery (Briggs 2004). Their high level ef culinary capacity made the NSLP an economically efficient and less resource-intensive program (for example, through bargains on seasonal produce, thrifty ingredient substitutions, and zero-waste practices like using vegetable peelings and turkey carcasses for making stock). The flexibility of cooking from scratch also allowed schools to serve culturally relevant meals that reflected and reproduced the tastes and traditions of particular communities (Hollingsworth 2012).

While the physical infrastructure and skill base for on-site production in US schools has largely eroded (PEW Trusts 2013), a growing number of communities are taking the first steps toward transitioning to scratch production (Collins 2012). Interventions designed to increase "culinary capacity," or the skills, time, and equipment needed to turn raw ingredients into freshly prepared meals, improve not only children's health and wellness (Cohen et al. 2012; Djang et al. 2016), but also their educational outcomes and school attendance (Belot and James 2011). Scratch cooking also directs more money to labor and ingredients rather than prepared foods (Tsui et al. 2013), and allows schools to serve more plant-based entrées that are less resource intensive than the beef, chicken, cheese, and fluid milk that are currently relied upon as the primary protein sources in the NSLP. The energy demands of the US food system could be reduced by up to 74 percent if the population were to shift to an energy efficient pescatarian diet (Canning et al. 2017),

Breaking from the "heat-and-serve" economy and building communitybased culinary capacity acts as a way station for "productive justice," or the ability of individuals and groups to actively shape the social and economic systems in which they live (Wright 2007). Minneapolis, Minnesota, Public Schools (MPS) offers one example of how schools can 
simultaneously transition to scratch cooking, promote experiential food

530 and nutrition education, and support a sustainable agricultural supply

531 chain (Minneapolis Public Schools 2017). MPS had very low culinary 532 capacity until it began investing in a kitchen renovation project and 533 FTS programming in 2012. The city built a central production kitchen 534 in the 1970s, where workers produced tens of thousands of pre-packed 535 lunches on a mechanized assembly line. These meals were trucked to "warming kitchens" in locations across the city where they were reheated in their plastic or aluminum containers and then distributed to kids in the cafeterias. Under the leadership of a new foodservice director, MPS embarked on an ambitious project to renovate the kitchens of all sixty-four of its buildings to accommodate scratch cooking (Boss 2016).

While the MPS project is still underway, early results suggest that transforming the social provisioning of school food has helped generate skilled "high-quality care jobs" that are more likely to be full-time and 544 to allow for more autonomy, creativity, and collaboration (Folbre 2006; 545 Schneider 2016). Investing in production kitchens has also helped MPS 546 build capacity from within, thereby increasing the "transformability" of school lunch as a social-ecological system (Walker et al. 2004). As it built culinary capacity, MPS pioneered the elimination of "ingredients of concern" from its supply chain and developed "clean label" recipes without 550 the additives found in products of lower nutritional quality (Minneapolis 551 Public Schools 2015). ${ }^{9}$ In addition, MPS uses its purchasing power to 552 support local producers and gives preference to minority growers and small farms with sustainable agricultural practices and fair labor standards.

Investing in structural changes to how school food is grown, prepared, and served, as Minneapolis has done, would help the NSLP advance feminist and ecological goals in tandem. The vast network of school kitchens and cafeterias in the US could be reimagined, and ultimately reconfigured, to develop a culinary skill base of adults trained to prepare healthy, sustainable, culturally relevant foods and a "taste base" of children

560 who have learned to accept or even desire foods that differ from the flattened-out tastes and expectations of the industrial food system (Carolan 2015).

563

564

565

566

567

568

569

570

571

572

\section{Procurement and participation for the public good}

Market-based mechanisms may also be able to effectively reorganize school lunch to promote care and sustainability if the procurement criteria encompass a holistic range of quality metrics (Morgan and Sonnino 2013). Rome, Italy, launched a "quality revolution" in 2001 that dramatically restructured school lunch procurement to prioritize seasonal, local, organic food, and "bio-dedicated" food chains that promote regional agricultural identity and global solidarity through fair trade (Liquori 2006). 
Rome's school lunch service is almost entirely privatized, but the contracts are awarded in a way that limits the overall market share of any single company, and caterers must be able to satisfy a broad set of criteria related to ecological sustainability, cultural identity, social justice, and labor standards (Liquori 2006).

Critical food studies scholars warn that the devolution of school lunch policy to the local level can lead to inequitable outcomes (Allen and Guthman 2006; Levine 2008; Morgan and Sonnino 2013). Local flexibility and participatory democracy coupled with strong national procurement standards can help mitigate this concern. To these ends, Brazil's Home Grown School Food program offers a compelling case: federal legislation mandates that 70 percent of the food served in schools is fresh or minimally processed and that 30 percent is sourced from local family farmers (Otsuki 2011). This nationwide stimulus for ethical consumption (Kleine and das Graças Brightwell 2015) protects against the further displacement of regional foodways by the corporate food regime (Monteiro and Cannon 2012). ${ }^{10}$ However, these laws came about only after civil society organizations exerted sustained pressure on legislators, demonstrating that transforming food systems requires citizen participation (Hassanein 2003).

In the vein of increasing participation in school food systems and establishing the conditions for productive justice, we suggest inviting children to grow, prepare, and serve their own school lunches. ${ }^{11}$ Such activities increase children's food awareness, skills, and confidence, which may have spillover effects into the home environment (Ensaff et al. 2015). These experiential opportunities should be sensitive to and educate students about the ways in which particular populations (such as African Americans during slavery and more recently Latino/a immigrants within the US context) have been exploited in the production of food, and encourage them to explore the ways in which these lasting legacies shape their attitudes and relationships to food labor.

School children themselves have at times been exploited in the production of food, for example on farms in Tanzania (Phillips and Roberts 2011),-and in cafeterias in the US (Levine 2008). It is therefore critical to ensure that students are the beneficiaries of their own labor and that such programs are designed to dismantle rather than reproduce systems of oppression. Furthermore, through the intentional design and delivery of inclusive and holistic programs that allow children to care for themselves, each other, and the environment, the social provisioning of school lunch can advance the feminist goal of breaking down the gendered, classed, and racialized distribution of caring responsibilities.

The NSLP's current system of only offering free lunches to children from poor families has the unintended consequence of reinforcing class divides and shaming those parents and children who participate (Poppendieck 2010). Advocates of a universal program convincingly demonstrate that 
617 providing free lunches to all children reduces the stigma of participation

618 and eliminates the time burden and administrative costs associated with

619 verifying income-based eligibility (Poppendieck 2010). From a pragmatic

620 standpoint, universal care policies help taxpayers better understand the

621 value of increased public provisioning (Folbre, Howes, and Leana 2012)

622 and the need for improving the quality of school lunches. The potential

623 for universal gains can help generate political pressure. Take South

624 Korea, for example: in 2010, a coalition of over 2,100 civic groups and

625 social organizations successfully demanded that the government provide

626 universally free school lunches made with local and organic ingredients

627 through programs managed by school districts, not private companies

628 (Kang 2011). The South Korean coalition intentionally leveraged the 629 demand for high-quality social services, in this case school lunch, to initiate

630 a more democratic arrangement of care and a more ecologically sustainable

631 food system.

632 A coalition politics that seeks to advance more democratic arrangement

633 of care within the US might look to the possibility for schools to play

634 a greater role in the social provisioning of food for other vulnerable

635 populations. For instance, cafeteria workers who currently hold part-

636 time positions could be hired full time to prepare affordable, nutritious,

637 ethically sourced meal "kits" and heat-and-serve meals for caregivers,

638 elderly, chronically ill, and disabled people who may not have the ability to

639 cook from scratch. This would help ease the gendered and classed burdens

640 of ethical consumption (Cairns, Johnston, and MacKendrick 2013), and

641 help families, especially women, manage competing care responsibilities

642 for populations whose needs are often pitted against each other in

643 policy discussions (Folbre, Howes, and Leana 2012). This would make

644 efficient use of school-based infrastructure that is frequently unused in

645 the afternoons, evenings, and weekends. Schools could also open their

646 cafeteria doors to allow the elderly and other vulnerable populations to eat

647 lunch alongside children and youth, which would reduce social isolation

648 and teach children of all genders to be both givers and receivers of care - a

649 step in the right direction for producing caring democratic citizens (Tronto 650 2013)..$^{12}$

651 Achieving these "high road" reforms rests on strengthening and 652 sustaining community support. This is a whole family issue, but children 653 and youth have perhaps the most at stake. School lunch impacts their 654 bodies and the economic and ecological systems they will inherit as 655 adults. They have agency to organize at the local level and to use social 656 media to stage mass actions that force policy change at state and national 657 levels. Organizing cafeteria workers to take a collective stand, as unionized 658 workers in three US cities have already done, is another way to begin 659 building the political power necessary to reorganize the social provisioning 660 of the NSLP (Gaddis 2014). However, this is a daunting task in the US, 
661

662

663

664

665

666

667

Q11658

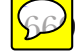

670

671

672

673

674

675

676

677

678

679

680

681

682

683

684

685

686

687

688

689

690

691

692

693

694

695

696

697

698

699

700

701

702

703

704

where decades of attacks on organized labor have created a hostile climate for the labor movement. They will need allies. "Whole worker organizing," whereby labor and community organizing go hand in hand to build sustained power for change (McAlevey 2016), helps us conceptualize how the efforts of both the receivers and givers of care could be harnessed for maximum impact. Finally, by making strategic connections to civil society organizations with intersecting concerns Black Lives Matter, frightfor 15.0rge, Slow Food International, 350.org, and La Via Campesina), this budding coalition of grassroots school lunch activists can amplify their voices and reach new allies until it has forged a coalition politics capable of forcing to play a more aggressive and proactive role in mediating crises of social reproduction and environmental destruction (Di Chiro 2008).

\section{CONCLUSION}

The US NSLP, and its reliance on "heat-and-serve" meals, serves as a cautionary tale to government agencies and civil society organizations that are funding school lunch programs as a way to advance sustainable development. Our analysis demonstrates why an alternative system of provisioning is necessary in order to maximize the public value of the NSLP, particularly in relation to care, ecology, and sustainability. The agenda we put forward builds on Morgan and Sonnino's (2013) framework for a moral economy of school food, but following Power's (2004) social provisioning methodology generates three caveats. First, we posit that a moral economy of school food cannot be realized without recognizing the value of the paid and unpaid care work that goes into feeding children and actively supporting this work as necessary to children's wellbeing. Second, we contend that a moral economy of school food social reproduction and ecological sustainability as mutually constitutive collective responsibilities. Third, we argue that a moral economy cannot be achieved without disrupting the entrenched power structures of the corporate food regime through intentional and confrontational forms of collective action and coalition politics (Di Chiro 2008).

Finally, we believe that existing public institutions and programs, like school lunch, deserve greater exploration as part of a broader agenda of action-oriented scholarship at the intersection of sustainability, care, and ecology. We agree with Power when she says, "Starting points matter because of where they take you and, as such, must be chosen with great care" (2004: 15). Endpoints matter too. The social provisioning methodology helps to guide a holistic analysis of complex social, political, and ecological systems; as an analytical approach, it stops short of radically reimagining possible alternatives and articulating strategies for transformation, which are made explicit within the tradition of 
705

706

707

708

709

710

711

712

713

714

715

716

717

718

719

720

721

722

723

724

725

726

727

728

729

730

731

732

733

734

735

736

737

738

739

740

741

742

743

744

745

746

747

748

emancipatory social science (Wright 2007). In making this claim, our intention is to underscore the analytical utility of the social provisioning methodology and to stimulate further research on how social provisioning might be actively reorganized in ways that simultaneously serve both feminist and ecological goals.

Jennifer Gaddis
University of Wisconsin-Madison - Civil Society and Community Studies
1300 Linden Drive, Madison, Wisconsin 53706, USA
e-mail: jgaddis@wisc.edu
Amy K. Coplen @0
Portland State University College of Urban and Public Affairs - Urban Studies and
Planning
506 SW Mill Street, Portland, Oregon 97207-0751, USA
e-mail: akcoplen@gmail.com
http://orcid.org/0000-0001-7711-8144

Jennifer Gaddis is Assistant Professor in Civil Society and Community Studies at the University of Wisconsin-Madison. Her research, teaching, and outreach focus on transitions to socially just and ecologically sustainable systems of production and consumption. The bulk of her work has been within the context of food systems, specifically school food programs and community-based food justice initiatives. She earned a PhD in Environmental Sociology from Yale University and a BS in Materials Science and Engineering from the University of Illinois at Urbana-Champaign.

Amy K. Coplen is a PhD candidate in Urban Studies at Portland State University, working at the intersection of food systems, labor, and social justice to explore how race, class, and gender shape our urban environments. She earned a BS in Chemistry and a BA in American Studies from the University of New Mexico, and a Masters of Environmental Management from Yale University.

\section{ACKNOWLEDGMENTS}

We would like to thank all the foodservice professionals engaged in the work of feeding children at school, as well as the many activists who are fighting for a just and sustainable food system. In addition, we would like to thank the two anonymous reviewers and the participants of the workshop on Sustainability, Ecology, and Care hosted by Friedrich Ebert Stiftung and the International Association for Feminist Economics for their 
helpful comments. Any remaining errors or oversights are our own. This research was funded by the National Science Foundation, grant number 1256925 .

\section{REFERENCES}

1 Despite a federal mandate to feed all needy children free of charge, few African American children in racially segregated southern states and northern cities received any benefit from the federal allocations until the victories of the civil rights movement in the late 1960s and early 1970s (Levine 2008).

2 At the time of our writing, conservative lawmakers in the House Freedom Gaucus have targeted the HHFKA as their frrst agenda item in a list of regulations and rules that they are advising President Trump to examine or revoke in his first 100 days in office (2016)

3 This includes both small regional firms and multinational corporations like Sodexo, Compass, and Aramarkł. These companies often hold contracts with other institutional purchasers (such as universities, hospitals, airports, and prisons).

${ }^{4}$ Like other care providers, unionized school foodservice workers are not likely to exercise their bargaining power because withdrawing their services (that is, going on strike) puts the very people they care for at risk (Folbre 2001).

5 Notably, body burdens are higher for populations in the US compared to those in Europe and Asia (Hites 2004).

${ }^{6}$ In addition, a mismatch in agricultural seasonality (most schools are not in session during the peak growing months of June-August) and issues of scale are also barriers that make it difficult for schools to shift their procurement to local farms.

7 According to a nationally representative survey, 88 percent of US adults support government-funded FTS programs (Reincke 2015).

8 The USDA awards up to US $\$ 5$ million annually in competitive grants to support FTS programs (USDA 2016b), but the total NSLP budget exceeds US $\$ 12$ billion.

9 Likewise, Saint Paul, Minnesota, Public Schools and Chicago, Illinois, Public Schools have also begun to prepare some recipes from scratch, which has resulted in greater autonomy to purchase local products and to use collective purchasing power to drive reforms further up the food chain (Stanley, Colasanti, and Conner 2012).

10 Notably, scholars have argued that the UN's embrace of public-private food partnerships allowed the corporate food regime to undermine public health in the global south (Monteiro and Cannon 2012).

11 Empowering both the givers and receivers of paid care is a strategy for increasing the quality of jobs and services (Folbre 2006; Glenn 2012).

12 There is precedent for such arrangements within the history of the NSLP (see for instance the September 1971 issue of the School Foodservice Journal for a profile of elderly feeding programs administered by school foodservice departments).

Alkon, Alison H. and Julian Agyeman. 2011. Cultivating Food Justice: Race, Class, and Sustainability. Cambridge, MA: MIT Press.

Allen, Patricia, Margaret FitzSimmons, Michael Goodman, and Keith Warner. 2003. "Shifting Plates in the Agrifood Landscape: The Tectonics of Alternative Agrifood Initiatives in California." Journal of Rural Studies 19(1): 61-75. 
793

794

795

796

797

798

799

800

801

802

803

804

805

806

807

808

809

810

811

812

813

814

815

816

817

818

819

820

821

822

823

824

825

826

827

828

829

830

831

832

833

834

835

836

Allen, Patricia and Julie Guthman. 2006. "From 'Old School' to 'Farm-to-School': Neoliberalization from the Ground Up." Agriculture and Human Values 23(4): 401-15.

Allen, Patricia and Carolyn Sachs. 2007. "Women and Food Chains: The Gendered Politics of Food." International Journal of Sociology of Food and Agriculture 15(1): $1-23$.

Bakker, Isabella. 2007. "Social Reproduction and the Constitution of a Gendered Political Economy." New Political Economy 12(4): 541-56.

Belasco, Warren. 1990/2014. Appetite for Change: How the Counterculture took on the Food Industry. Ithaca, NY: Cornell University Press.

Belot, Michèle and Jonathan James. 2011. "Healthy School Meals and Educational Outcomes." Journal of Health Economics 30(3): 489-504.

Bogardus, Kevin. 2010. "Lawmakers Scrutinize Food Service Company Over School Lunches." The Hill, September 26.

Born, Branden and Mark Purcell. 2006. "Avoiding the Local Trap: Scale and Food Systems in Planning Research." Journal of Planning Education and Research 26(2): 195-207.

Boss, Donna. 2016. "Facility Design Project of the Month: Minneapolis Public Schools." Foodservice Equipment and Supplies. http://fesmag.com/departments/facilitydesign-project-of-the-month/13661-lucy-craft-laney-community-school-and-roosevelthigh-school-in-the-minneapolis-public-schools-system.

Briefel, Ronette R., Ander Wilson, and Philip M. Gleason. 2009. "Consumption of LowNutrient, Energy-dense Foods and Beverages at School, Home, and Other Locations among School Lunch Participants and Nonparticipants." Journal of the American Dietetic Association 109(2): S79-90.

Briggs, Marilyn. 2004. Interviewed by Beth King, Oral History Project, Child Nutrition Archives, Institute of Child Nutrition, July 8.

Brown, Sandy and Christy Getz. 2008. "Privatizing Farm Worker Justice: Regulating Labor Through Voluntary Certification and Labeling." Geoforum 39(3): 1184-96.

Brownell, Kelly D. and Kenneth E. Warner. 2009. "The Perils of Ignoring History: Big Tobacco Played Dirty and Millions Died. How Similar is Big Food?” Milbank Quarterly 87(1): 259-94.

Busch, Lawrence and Carmen Bain. 2004. "New! Improved? The Transformation of the Global Agrifood System.” Rural Sociology 69(3): 321-46.

Canning, Patrick, Sarah Rehkamp, Arnold Waters, and Hamideh Etemadnia. 2017. "The Role of Fossil Fuels in the U.S. Food System and the American Diet." USDA Economic Research Service. https://www.ers.usda.gov/webdocs/publications/82194/err-224. pdf? $=42804$.

Cairns, Kate, Josée Johnston, and Norah MacKendrick. 2013. "Feeding the 'Organic Child': Mothering through Ethical Consumption.” Journal of Consumer Culture 13(2): 97-118.

Garmichael-Djang, Holly, Barbara Andersen, Tatiana Masters, Jan Vanslyke, and Blair Beadnell. 2016. "Key Ingredients for School Food Systems: An Evaluation of the Orfalea Foundation's School Food Initiative." The Foundation Review 8(2): 20-38.

Carolan, Michael. 2015. "Affective Sustainable Landscapes and Care Ecologies: Getting a Real Feel for Alternative Food Communities.” Sustainability Science 10(2): 317-29.

Centers for Disease Control and Prevention (CDC). 2009. "Fourth National Report on Human Exposure to Environmental Chemicals." Department of Health and Human Services, Centers for Disease Control and Prevention. https://www.cdc.gov/ exposurereport/pdf/fourthreport.pdf.

2017. "Child Obesity Facts: Prevalence of Childhood Obesity in the United States, 2011-2014." Centers for Disease Control and Prevention. https:/ / www.cdc.gov/ obesity/data/childhood.html. 
Clapp, Jennifer and Gyorgy Scrinis. 2017. "Big Food, Nutritionism, and Corporate Power." Globalizations 14(4): 578-95.

Cohen, Juliana, Liesbeth A. Smit, Ellen Parker, S. Bryn Austin, A. Lindsay Frazier, Christina D. Economos, and Eric B. Rimm. 2012. "Long-Term Impact of a Chef on School Lunch Consumption: Findings from a 2-Year Pilot Study in Boston Middle Schools." Journal of the Academy of Nutrition and Dietetics 112(6): 927-33.

Collins, Beth. 2012. "Can Schools Save Kids' Palates? Cooking from Scratch in Schools the Greatest Food Service Challenge of Our Time." Childhood Obesity 8(4): 323-6.

Confessore, Nicholas. 2014. "How School Lunch Became the Latest Political Battleground." New York Times, October 7.

Datar, Ashlesha and Nancy Nicosia. 2012. "Outsourcing Meals: Effects of Maternal Work on Children's School Meal Participation.” Social Service Review 86(4): 565-93.

Di Chiro, Giovanna. 2008. "Living Environmentalisms: Coalition Politics, Social Reproduction, and Environmental Justice.” Environmental Politics 17(2): 276-98.

DuPuis, E. Melanie and David Goodman. 2005. "Should We Go 'Home' to Eat? Toward a Reflexive Politics of Localism.” Journal of Rural Studies 21 (3): 359-71.

England, Paula, Michelle Budig, and Nancy Folbre. 2002. "Wages of Virtue: The Relative Pay of Care Work." Social Problems 49(4): 455-73.

England, Paula, Nancy Folbre, and Carrie Leana. 2012. "Motivating Care." In For Love and Money: Care Provision in the United States, edited by Nancy Folbre, 21-39. New York: Russell Sage Foundation.

Ensaff, Hannah, Charmaine Canavon, Ruth Crawford, and Margo Barker. 2015. "A Qualitative Study of a Food Intervention in a Primary School: Pupils as Agents of Change." Appetite 95: 455-65.

Federici, Silvia. 2004. Caliban and the Witch. New York: Autonomedia.

Fischer, Berenice and Joan Tronto. 1990. "Toward a Feminist Theory of Caring." In Circles of Care: Work and Identity in Women's Lives, edited by Emily K. Abel and Margaret K. Nelson, 35-62. Albany, NY: State University of New York Press.

Folbre, Nancy. 2001. The Invisible Heart: Economics and Family Values. New York: New Press. 2006. "Demanding Quality: Worker/Consumer Coalitions and 'High Road' Strategies in the Care Sector." Politics and Society 34(1): 1-21.

Folbre, Nancy, Candace Howes, and Carrie Leana. 2012. "A Care Policy and Research Agenda." In For Love and Money: Care Provision in the United States, edited by Nancy Folbre, 183-204. New York: Russell Sage Foundation.

Food and Agriculture Organization. 2010. "Sustainable Diets and Biodiversity: Directions and Solutions for Policy, Research and Action." Nutrition and Consumer Protection Division, Food and Agriculture Organization. http://www.fao.org/docrep/016/ i3004e/i3004e.pdf.

2015. "The State of Food Insecurity in the World." Food and Agriculture Organization. http://www.fao.org/3/a-i4646e.pdf.

Gaddis, Jennifer E. 2014. "Mobilizing to Re-value and Re-skill Foodservice Labor in U.S. School Lunchrooms: A Pathway to Community-level Food Sovereignty?" Radical Teacher 98: 15-21.

Galt, Ryan. 2013. "The Moral Economy Is a Double-edged Sword: Explaining Farmers' Earnings and Self-exploitation in Community-Supported Agriculture." Economic Geography 89(4): 341-65.

Gibson, Kristina E. and Sarah E. Dempsey. 2015. "Make Good Choices, Kid: Biopolitics of Children's Bodies and School Lunch Reform in Jamie Oliver's Food Revolution." Children's Geographies 13(1): 44-58.

Gottlieb, Robert and Anupama Joshi. 2010. Food Justice. Cambridge, MA: MIT Press.

Gray, Margaret. 2014. Labor and the Locavore: The Making of a Comprehensive Food Ethic. Berkeley: University of California Press. 
Guthman, Julie. 2008. "Neoliberalism and the Making of Food Politics in California." Geoforum 39(3): 1171-83. 2011. Weighing in: Obesity, Food Justice, and the Limits of Capitalism. Berkeley: University of California Press.

Hager, Mary. 2015. "Itadakimasu - Let's Eat!" Nutrition Today 50(6): 273-6.

Hassanein, Neva. 2003. "Practicing Food Democracy: A Pragmatic Politics of Transformation." Journal of Rural Studies 19(1): 77-86.

Heller, Martin C. and Gregory A. Keoleian. 2003. "Assessing the Sustainability of the U.S. Food System: A Life Cycle Perspective.” Agricultural Systems 76(3): 1007-41.

Himmelweit, Susan. 2002. "Making Visible the Hidden Economy: The Case for Genderimpact Analysis of Economic Policy." Feminist Economics 8(1): 49-70.

2007. "The Prospects for Caring: Economic Theory and Policy Analysis." Cambridge Journal of Economics 31 (4): 581-99.

Hites, Ronald A. 2004. "Polybrominated Diphenyl Ethers in the Environment and in People: A Meta-analysis of Concentrations." Environmental Science and Technology 38(4): 945-56.

Hollingsworth, Melba. 2012. Interviewed by Beverly Cross, Oral History Project, Child Nutrition Archives, Institute for Child Nutrition, July 18, 2012.

Horrigan, Leo, Robert S. Lawrence, and Polly Walker. 2002. "How Sustainable Agriculture Can Address the Environmental and Human Health Harms of Industrial Agriculture." Environmental Health Perspectives 110(5): 445-56.

Jaffee, Daniel. 2012. "Weak Coffee: Certification and Co-Optation in the Fair Trade Movement." Social Problems 59(1): 94-116.

Kang, Mi Ok. 2011. "Organic School Lunch Programs in South Korea." In School Food Politics: The Complex Ecology of Hunger and Feeding in Schools Around the World, edited by Sarah A. Robert and Marcus B. Weaver-Hightower, 120-40. New York: Peter Lang.

Kleine, Dorothea and Maria das Graças Brightwell. 2015. "Repoliticising and Scaling-up Ethical Consumption: Lessons from Public Procurement for School Meals in Brazil." Geoforum 67: 135-47.

Kloppenburg, Jack and Neva Hassanein. 2006. "From Old School to Reform School?" Agriculture and Human Values 23(4): 417-21.

Komisar, Lucy. 2011. "How the Food Industry Eats Your Kid's Lunch." New York Times, December 3.

Krimsky, Sheldon. 2002. Hormonal Chaos: The Scientific and Social Origins of the Environmental Endocrine Hypothesis. Baltimore, MD: Johns Hopkins University Press.

Levine, Susan. 2008. School Lunch Politics: The Surprising History of America's Favorite Welfare Program. Princeton, NJ: Princeton University Press.

Levkoe, Charles Z. 2011. "Towards a Transformative Food Politics." Local Environment 16(7): 687-705.

Liquori, Toni. 2006. "Rome, Italy: A Model in Public Food Procurement: What Can the United States Learn?” Briefing Paper, Liquori and Associates. http://www.baum forum.org/downloads_conference-presentations/sf06/rome_briefing.pdf.

Lyson, Helena C. 2016. "National Policy and State Dynamics: A State-level Analysis of the Factors Influencing the Prevalence of Farm to School Programs in the United States." Food Policy 63: 23-35.

MacKendrick, Norah. 2014. "More Work for Mother: Chemical Body Burdens as a Maternal Responsibility." Gender and Society 28(5): 705-28.

McAlevey, Jane F. 2016. No Shortcuts: Organizing for Power in the New Gilded Age. New York: Oxford University Press.

McMahon, Martha. 2005. "Engendering Organic Farming.” Feminist Economics 11(3): 134-40. 
Meadows, Mark. 2016. "Rules, Regulations, and Executive Orders to Examine, Revoke, and Issue." Special Report from the Office of Congressman Mark Meadows. https:// meadows.house.gov/first-100-days.

Minkoff-Zern, Laura-Anne. 2014. "Challenging the Agrarian Imaginary: Farmworker-Led Food Movements and the Potential for Farm Labor Justice." Human Geography 7(1): $85-101$.

Minneapolis Public Schools. 2015. "Ingredients of Concern." Culinary and Wellness Services, Minneapolis Public Schools. http://nutritionservices.mpls.k12.mn.us/ ingredients_of_concern.

2017. "Culinary and Wellness Services News." Culinary and Wellness Services, Minneapolis Public Schools. http://nutritionservices.mpls.k12.mn.us/news.

Mirtcheva, Donka M. and Lisa M. Powell. 2009. "Participation in the National School Lunch Program: Importance of School-Level and Neighborhood Contextual Factors." Journal of School Health 79(10): 485-94.

Monteiro, Carlos A. and Geoffrey Cannon. 2012. "The Impact of Transnational 'Big Food' Companies on the South: A View from Brazil." PLoS Med 9(7): e1001252.

Morgan, Kevin and Roberta Sonnino. 2013. The School Food Revolution: Public Food and the Challenge of Sustainable Development. New York: Routledge.

Moss, Ashley, Sylvia Smith, Dawn Null, Sara Long Roth, and Ulrike Tragoudas. 2013. "Farm to School and Nutrition Education: Positively Affecting Elementary SchoolAged Children's Nutrition Knowledge and Consumption Behavior." Childhood Obesity 9(1): 51-6.

Nakano Glenn, Evelyn. 2012. Forced to Care: Coercion and Caregiving in America. Cambridge, MA: Harvard University Press.

National Farm to School Network. 2016a. "About National Farm to School Network." National Farm to School Network. http:/ /www.farmtoschool.org/about. 2016b. "The Benefits of Farm to School." National Farm to School Network. http://www.farmtoschool.org/Resources/BenefitsFact Sheet.pdf.

Nelson, Julie. 1996. Feminism, Objectivity and Economics. New York: Routledge.

Nestle, Marion. 2013 [2002]. Food Politics: How the Food Industry Influences Nutrition and Health. Vol. 3. Berkeley: University of California Press.

Newbold, Retha R., Elizabeth Padilla-Banks, Wendy N. Jefferson, and Jerrold J. Heindel. 2008. "Effects of Endocrine Disruptors on Obesity." International Journal of Andrology 31(2): 201-8.

Office of Disease Prevention and Health Promotion. 2017. "Dietary Guidelines." Office of Disease Prevention and Health Promotion. https://health.gov/dietaryguidelines/.

Ogden, Cynthia L., Margaret D. Carroll, Brian K. Kit, and Katherine M. Flegal. 2012. "Prevalence of Obesity and Trends in Body Mass Index among U.S. Children and Adolescents, 1999-2010." Journal of the American Medical Association 307(5): 483-90.

Oostindjer, Marije, Jessica Aschemann-Witzel, Qing Wang, Silje Elisabeth Skuland, Bjørg Egelandsdal, Gro V. Amdam, Alexander Schjøll, Mark C. Pachucki, Paul Rozin, Jarrett Stein, Valerie Lengard, and Ellen van Kleef. 2016. "Are School Meals a Viable and Sustainable Tool to Improve the Healthiness and Sustainability of Children's Diet and Food Consumption? A Cross-national Comparative Perspective." Critical Reviews in Food Science and Nutrition

Otero, Gerardo, Gabriela Pechlaner, Giselle Liberman, and Efe Gürcan. 2015. "The Neoliberal Diet and Inequality in the United States." Social Science and Medicine 142: $47-55$.

Otsuki, Kei. 2011. "Sustainable Partnerships for a Green Economy: A Case Study of Public Procurement for Home-grown School Feeding." Natural Resources Forum 35(3): 21322. 
Pechlaner, Gabriela and Gerardo Otero. 2010. "The Neoliberal Food Regime: Neoregulation and the New Division of Labor in North America." Rural Sociology 75(2): 179-208.

PEW Charitable Trusts and the Robert Wood Johnson Foundation. 2013. "Serving Healthy School Meals U.S. Schools Need Updated Kitchen Equipment.” Report from The Pew Charitable Trusts and the Robert Wood Johnson Foundation. http://www. pewtrusts.org/ /media/assets/2013/12/kits_equipment_report.pdf.

Phillips, Kristin D. and Daniel Roberts. 2011. "Cultivating Schools for Rural Development: Labor, Learning, and the Challenge of Food Sovereignty in Tanzania." In School Food Politics: The Complex Ecology of Hunger and Feeding in Schools Around the World, edited by Sarah A. Robert and Marcus B. Weaver-Hightower, 71-93. New York: Peter Lang.

Poppendieck, Janet. 2010. Free for All: Fixing School Food in America. Vol. 28. Berkeley: University of California Press.

Power, Marilyn. 2004. "Social Provisioning as a Starting Point for Feminist Economics." Feminist Economics 10(3): 3-19.

Ralston, Katherine, Constance Newman, Annette Clauson, Joanne Guthrie, and Jean Buzby. 2008. "The National School Lunch Program: Background, Trends, and Issues." USDA Economic Research Report Number 61.

Reincke, Kathy. 2015. "Poll: Nine Out of Ten Americans Want to Keep School Meals Healthy." W.K. Kellogg Foundation. https://www.wkkf.org/news-and-media/article/ 2015/08/ poll-nine-out-of-10-americans-want-to-keep-school-meals-healthy.

Robert, Sarah A., and Marcus B. Weaver-Hightower, eds. 2011. School Food Politics: The Complex Ecology of Hunger and Feeding in Schools Around the World. New York: Peter Lang.

Rushing, Keith, Gary Anderson, and Julie Boettger. 2016. "Key Performance Indicators (KPIs): Practical Applications." Paper presented at the Annual National Conference of the School Nutrition Association, July 10-13, San Antonio, TX.

Sandler, Jen. 2011. "Reframing the Politics of Urban Feeding in U.S. Public Schools: Parents, Programs, Activists, and the State." In School Food Politics: The Complex Ecology of Hunger and Feeding in Schools Around the World, edited by Sarah A. Robert and Marcus B. Weaver-Hightower, 25-45. New York: Peter Lang.

Schneider, Ashley. 2016. "MPS: A Day in the Life of School Food." Presentation as part of the "Cooks and Caretakers: Engaging Workers as Partners in Farm-toSchool" workshop at the National Farm-to-Cafeteria Conference, June 2-4, Madison, WI.

Schwartz, Marlene B. 2007. "The Influence of a Verbal Prompt on School Lunch Fruit Consumption: A Pilot Study." International Journal of Behavioral Nutrition and Physical Activity 4(6): https://doi.org/10.1186/1479-5868-4-6.

Service Employees International Union. 2005. "Evaluation of Outsourcing in the Public Sector." Service Employees International Union, Local 1000. https:/ / www.inthepublic interest.org/wp-content/uploads/Evaluation_of_Outsourcing_in_the_Public_Sector. pdf.

Stanley, Laura, Kathryn Colasanti, and David Conner. 2012. "A 'Real Chicken' Revolution: How Two Large Districts are Shifting the School Poultry Paradigm with Scratch Cooking." Childhood Obesity 8(4): 384-7.

Tabb, Michelle M. and Bruce Blumberg. 2006. "New Modes of Action for Endocrinedisrupting Chemicals." Molecular Endocrinology 20: 475-82.

Taras, Howard. 2005. "Nutrition and Student Performance at School." Journal of School Health 75(6): 199-213.

Tronto, Joan C. 2013. Caring Democracy: Markets, Equality, and Justice. New York: NYU Press. 
Tsui, Emma K., Jonathan Deutsch, Stefania Patinella, and Nicholas Freudenberg. 2013. "Missed Opportunities for Improving Nutrition through Institutional Food: The Case for Food Worker Training." American Journal of Public Health 103(9): e14-20.

UNITE HERE! 2013. "Healthy Kids First: Why Cafeteria Workers Want to Cook Fresh Meals in New Haven Public Schools." Unite Here Local 2017. http://www.realfood realjobs.org/wp-content/uploads/NH-Cafeteria-Report-for-web.pdf.

U.S. Department of Agriculture (USDA). 2014. "Richard B. Russell National School Lunch Act." https://www.fns.usda.gov/sites/default/files/NSLA.pdf. usda.gov/. 2016a. "The Farm to School Census." https://farmtoschoolcensus.fns. 2016b. "Community Food Systems." http://www.fns.usda.gov/farmtoschool/ farm-school-grant-program. 2017a. "Federal Cost of School Food Programs." https://www.fns.usda.gov/ sites/default/files/pd/cncost.pdf. 2017b. "National School Lunch Program: Participation and Lunches Served" https://www.fns.usda.gov/sites/default/files/pd/ slsummar.pdf.

Walker, Brian, Crawford S. Holling, Stephen R. Carpenter, and Ann Kinzig. 2004. "Resilience, Adaptability and Transformability in Social-Ecological Systems." Ecology and Society 9(2): 5-13.

Wood-Wright, Natalie. 2016. "New U.S. Dietary Guidelines Ignore Broad Support for Food Sustainability." https://hub.jhu.edu/2016/03/11/dietary-guidelines-sustain ability-survey/.

Woodward-Lopez, Gail, Janice Kao, Kristin Kiesel, Markell Lewis Miller, Maria Boyle, Soledad Drago-Ferguson, Ellen Braff-Guajardo, and Patricia Crawford. 2014. "Is Scratch-cooking a Cost-effective Way to Prepare Healthy School Meals with U.S. Department of Agriculture Foods?" Journal of the Academy of Nutrition and Dietetics 114(9): 1349-58.

World Food Programme. 2011. "Feed Minds, Change Lives: School Feeding, the Millennium Development Goals and Girls' Empowerment." http://www.un.org/en/ ecosoc/innovfair2011/docs/wfp.pdf. 2016. "Home Grown School Meals." https://www.wfp.org/our-work/our- 